HID 45 (2018)

\title{
ORÍGENES DEL MONASTERIO DE SAN LEANDRO Y SU FUSIÓN CON EL EMPAREDAMIENTO DE SAN PEDRO DE SEVILLA. SIGLOS XIII-XVI ${ }^{1}$
}

\author{
ORIGINS OF THE MONASTERY OF SAN LEANDRO AND ITS FUSION \\ WITH THE WALLING-UP OF SAN PEDRO OF SEVILLE. \\ $13^{\mathrm{TH}}-16^{\mathrm{TH}}$ CENTURIES
}

\author{
SALVADOR GUIJO PÉREZ \\ Universidad Pablo de Olavide de Sevilla \\ salvadorguijo@hotmail.com ORCID: https://orcid.org/0000-0002-3768-8430
}

RESUMEN: El artículo trata el tema de la fundación del Real Monasterio de San Leandro y sus distintos emplazamientos, situando su nacimiento en el contexto de la Conquista de Sevilla, pudiendo reconocerse como de origen fernandino y anterior al siglo XIV. Para llegar a esta conclusión es preciso realizar un estudio del contexto social, histórico y religioso de la época. Para ello hemos repasado los orígenes de la Orden de San Agustín y sus dos grandes uniones de 1244 y 1256, así como la llegada de la Orden Agustiniana a la ciudad de Sevilla. Del mismo modo, resulta significativo en nuestro estudio la fusión que el Monasterio tuvo con la comunidad de religiosas de San Pedro en 1516 -Emparedamiento de San Pedro-, como un hecho transformante tanto de la comunidad de San Leandro como de su patrimonio en los últimos momentos medievales de la historia de la ciudad de Sevilla.

Palabras Clave: Convento San Leandro; emparedamiento San Pedro; emparedadas; Orden San Agustín; Conquista de Sevilla; fundación Monasterio San Leandro; orígenes agustinos en Sevilla.

ABSTRACT: The article treats the topic of the establishment of the Royal Monastery of San Leandro and their different locations, placing his birth in the context of the conquest of Seville, and can be recognized in the times of Fernando III and pre-14 th century. To reach this conclusion, it is necessary to conduct a study

Recibido: 30-7-2017; Aceptado: 2-2-2018; Versión definitiva: 7-2-2018.

1. Abreviaturas utilizadas: $\mathrm{AMSL}=$ Archivo Monacal del convento de San Leandro; $\mathrm{LPMSL}=$ Libro de Protocolo del monasterio de San Leandro; AHPSPN = Archivo Histórico Provincial de Sevilla y al fondo documental de los Protocolos Notariales, ACS = Archivo Catedral de Sevilla.

Copyright: (C) Editorial Universidad de Sevilla. Este es un artículo de acceso abierto distribuido bajo los términos de la licencia de uso y distribución Creative Commons Reconocimiento-No-ComercialSinObraDerivada 4.0 (CC BY-NC-ND 4.0) 
of the social, historical and religious context of the time. To this end, we have reviewed the origins of the Order of St. Augustine and their two big unions of 1244 and 1256, as well as the arrival of the Augustinian Order in the city of Seville. In the same way, it is significant in our study the fusion that the Monastery had with the community of sisters of San Pedro in 1516 -the walling-up of San Pedro-, as a transforming both the San Leandro community and its heritage in the last medieval moments of the history of the city of Seville.

KEYWORDS: Convent San Leandro; walling-up San Pedro; recluses; Order St. Augustine; Conquest of Seville; Founding of San Leandro monastery; Augustinian origins in Seville.

\section{INTRODUCCIÓN}

El proceso de cristianización de la ciudad de Sevilla que se lleva a cabo tras la conquista es un fenómeno bien conocido. Y es que bien hizo Abul Beka, el rondeño, en cantar la pérdida de Sevilla en sentida elegía, pues era entonces sin duda la ciudad más hermosa de Península Ibérica. Los viajeros musulmanes la comparaban a Bagdad y los conquistadores castellanos la ensalzaron como arquetipo de maravillas $^{2}$. Varias civilizaciones habían dejado su huella a orillas del caudaloso río: romanos, visigodos $\mathrm{y}$, sobre todo, musulmanes.

Pero el periodo de dominación musulmana terminó tras el proceso de conquista cristiana. Fue Fernando III, rey de Castilla, apodado y canonizado como santo, quien logró la liberación de la ciudad y a quien se le debe el contexto de la misma a la hora de estudiar el fenómeno que nos ocupa. A partir de la instauración de su sede metropolitana, la erección de sus parroquias y la fundación de conventos en la ciudad recién conquistada, se tejió toda una trama de centros, instituciones y comunidades religiosas, tanto seculares como regulares, que daban respuesta a las demandas espirituales de la nueva población que se iba asentando en la capital del Guadalquivir. Se trató de un fenómeno muy temprano, paralelo o inmediato al proceso de Repartimiento, en el que tuvo un papel primordial la propia Corona, ya que de alguna manera esa cristianización de Sevilla formaba parte de la labor de reorganización a la que se sometió la ciudad recién conquistada y su territorio ${ }^{3}$.

\section{Orígenes de la Orden de SAN Agustín}

Para comprender la fundación y orígenes del monasterio de San Leandro, es necesario además de analizar el contexto social e histórico de la ciudad de Sevilla en el siglo XIII, conocer el contexto religioso y espiritual de su propio carisma

2. Abul Beka Saleh, hijo del Jerife de Ronda, lloró en delicados versos la caída de Sevilla. El original se conserva completo en Almakkari; Madrazo 1884, p. 492.

3. Borrero Fernández 1995; Sánchez Herrero 1984; Montes Romero-Camacho 1987. 
fundacional. Por este motivo, es obligatorio retrotraerse a san Agustín, así como a la fundación de la orden Agustiniana y su Regla, que será la más generalizada a la vez que utilizada por otros institutos y órdenes junto a la de san Benito en los inicios del monacato.

En Hipona, en el año 391, san Agustín fue ordenado sacerdote. En aquella ciudad africana levantó su primer monasterio, y se hizo acompañar de un pequeño grupo de hermanos que vivían en común a inspiración de las primitivas comunidades cristinas de Jerusalén. Posteriormente, fue consagrado obispo de Hipona y entre sus primeros mandatos se encontró el levantamiento de otro monasterio, esta vez femenino. La Regla monacal de San Agustín se extendió rápidamente por África, llegando a Europa entre los siglos V y VI por lo monjes que huían de la persecución de los vándalos. En el año 569 se tuvo constancia de que hubo colonia monástica en la costa levantina con el abad Donato y 70 monjes, que importaron en su huída de África copiosos códices, incluida la Regla de San Agustín. Y así, el ideal monástico agustiniano se extendió por las provincias Cartaginense, Bética y Lusitana, pese al anticristianismo sarraceno ${ }^{4}$.

Tras un largo periodo de decadencia por la preeminencia de otras reglas como la de San Benito ${ }^{5}$, el monaquismo agustiniano se multiplicó por Córdoba (1236), Sevilla (1248), Cartagena (1256), Aguasvivas (1239), Valencia (1240), Formentera (1250), al socaire de las conquistas de san Fernando, Alfonso X el Sabio y Jaime I el Conquistador ${ }^{6}$. Eran eremitorios y cenobios autónomos que profesaron la Regla de San Agustín. Así, muchos monasterios y capítulos catedralicios utilizaron esta Regla como norma de vida. Durante este periodo, el Papa Inocencio IV con la bula Incumbit nobis, el 16 de diciembre de 1243, inició la unión de diferentes comunidades eremíticas de la Toscana bajo la Regla Agustiniana. En marzo de 1244, los ermitaños tuvieron el capítulo de fundación en Roma, por el cual se llevó a cabo la unión.

Sin embargo, mayor importancia tuvo la denominada "Gran Unión de 1256", bajo el pontificado de Alejandro IV, que quiso seguir la decisión consolidada por los Papas Gregorio IX e Inocencio IV en relación a la generalización de la Regla Agustiniana conforme a los deseos del Concilio Lateranense IV de adoptar Reglas comunes existentes ${ }^{7}$. Este deseo llevó al Papa bajo la dirección del Cardenal Annibaldi, a la creación jurídica de la Orden de Ermitaños de San Agustín con la "Gran Unión de 1256", fusionando a Juambonitas, Guillermitas, Brittínos, etc.

4. Cilleruelo 1966; Gavignan 1962; Gavignan 1989; Gutiérrez 1980, 1977, 1971. Citado por Rodríguez Díez 1992, p. 134.

5. El periodo de decadencia de la Regla de San Agustín es también llamado "siglos de hierro", durante este periodo la Regla Agustina deja de utilizarse en gran parte de Europa por haber decretado Carlomagno en el Concilio de Aquisgrán, celebrado en el año 817, la imposición de la Regla de San Benito en su imperio Franco. San Nicolás 1736, p. 316.

6. Azevedo 1699; Crusenius 1623; Frías 1956; Herrera 1644; Jordán 1704; López Bardón 1903, 1914; Márquez 1608; Maturana 1912, 1913; Orozco 1551; Rodríguez 1927; Román y Zamora 1569, 1571, 1572. Citado por Rodríguez Díez 1992 p. 134.

7. Estrada Robles 1988, pp. 25-191; En la historia del monacato han adoptado la Regla de San Agustín unos 146 institutos de varones y 212 de monjas, catalogados en Trape 1978.

8. El Papa Alejandro IV, mediante la Bula Licet Ecclesiae Catholicae, de 9 de abril de 1256, confirmó una unión de ermitaños que seguían la Regla de San Agustín con otra que seguía la Regla 
Todos ellos quedaron sujetos a la obediencia de un mismo Prior General, Lanfranco Septala de Milán, de origen juambonita, en capítulo celebrado en Santa María del Pópulo de Roma, quien impuso su poder sobre 180 casas religiosas repartidas por toda Europa. Tras esta unión, la Orden de San Agustín quedó como tercera Orden de las cuatro Mendicantes junto a dominicos, franciscanos y carmelitas. Las primeras constituciones de Ratisbona de 1290 consolidaron la nueva estructura jurídica agustiniana ${ }^{9}$. Estos cambios respondieron a un periodo convulso donde nuevas herejías florecieron y era necesario un mayor control y autoridad dentro de la Iglesia. Con esta medida las diferentes comunidades religiosas existentes eran reguladas bajo una regla fidedigna con el Evangelio y la doctrina de la Iglesia.

En la Península Ibérica en el año siguiente a la “Gran Unión” jurídica de 1256 fue nombrado Fray Arnulpho como Prior provincial de los Hermanos Ermitaños de San Agustín, es decir, de la Provincia Hispaniae o Castilla ${ }^{10}$ con Vicariato de Portugal, que se erigió posteriormente en Provincia Lusitana en 1482. También en 1295 se creó como segunda Provincia la del Reino de Aragón, desmembrada de Castilla y extendida por Cataluña, Valencia y Baleares. Igualmente, nacida de Castilla se creó, en 1527, la tercera Provincia con el nombre de Bélica o Andalucía, que se fusionó de nuevo en 1541 con la Provincia de Castilla para independizarse ya con mayor madurez en $1582^{11}$.

La orden femenina llegó de la mano de la masculina y fue coetánea a la primera. Como ya hemos mencionado, el mismo san Agustín en vida, creó junto con el monasterio masculino uno femenino. En él dejó como priora a su propia hermana, una vez fallecida ésta, el monasterio entró en crisis, y el desorden y la inestabilidad se apoderaron del mismo. San Agustín fue precursor a los pasos de Inocencio IV, en 1244, y para solucionar el problema se carteó con la nueva superiora e introdujo su Regla para el funcionamiento de la comunidad, que ya se vivía en los monasterios de varones. A partir de ahí, la Regla de San Agustín se generalizó para ambas ramas. Posteriormente, con la unión de 1244, junto con los conventos de frailes se erigieron de igual modo los conventos de hermanas de vida contemplativa, buscando con ello grandes espacios de oración y contemplación. Estas casas de la Segunda Orden, hoy conocidas como Agustinas de Vida Contemplativa, estaban formados por mujeres que a ejemplo de san Agustín vivían en comunidad con un solo corazón y una sola alma en Dios ${ }^{12}$.

Benedictina y a la que se unieron los mencionados Ermitaños Toscanos, todos ellos unidos bajo la observancia de la Regla Agustina.

9. Aramburu Cendoya 1966; Empoli 1628. Citado por Rodríguez Díez 1992, p. 135.

10. Tirón 1846, p. 426. "El monasterio de San Leandro estuvo en su principio sujeto a los provinciales de Castilla o por lo menos al Prior General, según consta en los registros; pero con el transcurso del tiempo pasaron a vivir bajo la jurisdicción del arzobispo de aquella diócesis".

11. Llordén 1956; Gago Fernández 1963; Sanz Pascual 1948; Purificación 1642. Citado por Rodríguez Díez 1992, p. 136.

12. Orozco 1824, p. 11. En el capítulo 1.2 se transcribe este apartado tan personal y propio de san Agustín: Primum, propter quod in unum estis congregati, ut unánimes habitetis in domo, \& sit vobis una, \& cor unum in Deo. Es decir, ante todo, que habitéis unánimes en la casa y tengáis una sola alma y un solo corazón en camino hacia Dios. Este es el motivo por el que, deseosos de unidad, os habéis congregado. Confróntese las citas bíblicas del libro de los Salmos, cap. 67, vers. 7 y de Hechos de los 


\section{Llegada de la Orden Agustiniana a Sevilla}

\subsection{Primera Orden}

La presencia de los agustinos como orden recién fusionada en Sevilla se remonta al momento inmediato de la Conquista cristiana de la ciudad por el rey Fernando III en 1248. Fue por designio del mismo rey el establecimiento de dicha orden en la ciudad. El historiador Ortiz de Zúñiga detalló un elenco de conventos cuyas fundaciones se remontaban a la conquista de la ciudad. Entre ellos citó al que conocemos bajo el título de San Agustín, más conocido como la Casa Grande, siendo la primera presencia de los agustinos en la ciudad de Sevilla, al mismo tiempo que lo hicieron otras órdenes religiosas en la misma ciudad ${ }^{13}$. Del mismo modo, el historiador agustino Tomás de Herrera ${ }^{14}$ indicó también el año 1248 como fecha de fundación del citado convento, mientras que Arana de Varflora señaló la de $1249^{15}$. Con un argumentario del siglo XX, el padre Llordén confirma la fecha fundacional de $1248^{16}$, aunque hubo otros historiadores que incluso llegaron a retrasar su datación hasta el año $1292^{17}$. Actualmente, podemos encontrar la duda fundacional entre el año de la Conquista y el siguiente. Para resolver este dilema podemos afirmar que la fundación teórica del convento pudo realizarse en 1248 , mientras que en la práctica fuera realizada en el año 1249. Y esto debe pesar mucho para dejar constancia de la existencia de conventos de frailes agustinos anteriores a la gran unión de la Orden, anteriormente citada (1256), pues no se concibe fácilmente que en tan corto espacio de tiempo se abrieran tantas casas con tantos religiosos nativos adultos. Cabe, pues, pensar en la existencia anterior de monjes agustinos existentes en la Península Ibérica, que se unieron a la nueva forma jurídica de la Orden ${ }^{18}$.

Entre los signos de antigüedad de este convento, no el único, se conserva una Bula del Papa Urbano IV de 1262, en la que se concedían diversas gracias a la comunidad de frailes agustinos allí establecidos años atrás ${ }^{19}$. En el año 1292 cambió de lugar a un nuevo solar en la puerta de Carmona donado por la familia Arias

Apóstoles cap. 4, vers. 32. San Alonso de Orozco en su explicación de este apartado de la Regla recoge que san Agustín da a entender el fin al que son llamados a la religión, no solo para que vistan un paño, coman a una mesa u oren juntos, sino que la religión va más allá, en la unidad del corazón, y en ser unos en espíritu, amándonos en Dios. Orozco 1824, pp. 57 y 58.

13. Ortiz de Zúñiga 1796, p. 59.

14. Herrera 1652, p. 113.

15. Arana de Varflora 1789, p. 47.

16. Llordén 1944, p. 153; Gil Prieto 1930, p. 8 e Iturbe Saíz 1994, pp. 861-863.

17. La fundación del convento se relaciona con la compra por Arias Yáñez de unas casas extramuros de la Puerta de Carmona que eran propiedad de unas religiosas del Espíritu Santo dedicadas a adoctrinar niñas. Al respecto, véase Martínez de Aguirre 1992, p. 111.

18. Carmona Moreno 2007, p. 171.

19. Anónimo 1700. Citado por Iturbe Saiz, 1994, p. 863 y por Sánchez Pérez 2001, p. 388. Éste cita también a Martínez de Aguirre 1992, p. 110, donde no prueba nada en su discrepancia. Citado por Carmona Moreno 2007, p. 171. 
Yánez. Más tarde, los Ponce de León, Duques de Arcos, erigieron su sepulcro familiar en la capilla mayor de la iglesia conventual.

La rama masculina de los agustinos llegó a tener en Sevilla hasta tres establecimientos, la mencionada Casa Grande de San Agustín establecida cerca de los Caños de Carmona y de dicha puerta de la ciudad, el Colegio de San Acacio y el Convento de Nuestra Señora del Pópulo ${ }^{20}$. Todos ellos fueron desamortizados.

\subsection{Segunda Orden}

La vida cenobítica femenina en la ciudad de Sevilla era floreciente de igual modo que la masculina en el periodo fundacional de la ciudad. Analizando este contexto, la vida cenobítica femenina existente en este primer periodo de la ciudad, la segunda mitad del siglo XIII, fue dominada por la de los grandes monasterios sevillanos: San Clemente ${ }^{21}$, Santa Clara ${ }^{22}$, San María de las Dueñas ${ }^{23}$ y, tras el estudio de la documentación aportada, como no, San Leandro. Es difícil afirmar con rotundidad su erección debido al desconocimiento de la fecha exacta de fundación del monasterio, aunque como afirmaremos posteriormente, será el año 1249 o muy poco después en común acuerdo con otros historiadores ${ }^{24}$. Dificultad también reconocida por la profesora Mercedes Borrero, a la hora de datar el de Santa María de las Dueñas ${ }^{25}$. Los dos primeros fueron fundación regia, uno bajo la Regla Benedictina del Císter y el otro, Santa Clara, como su propio nombre indica, fue organizado con la Regla Franciscana de las Clarisas ${ }^{26}$. Por el contrario, el de Santa María de las Dueñas, también cisterciense, se presenta como ejemplo de fundación de origen privado, siendo el primero documentado de la ciudad. Éste podría ser también el caso del agustino de San Leandro, aunque del mismo modo la documentación evidencia la protección que la Corona profesó a las hijas de san Agustín, prácticamente desde sus orígenes, sobre todo a partir del reinado de Fernando IV.

En definitiva, la presencia femenina agustiniana no tardó mucho en llegar a la ciudad de Sevilla, siendo el que nos ocupa el más antiguo de los cuatro conventos de agustinas que hubo en la ciudad y el único durante el periodo estudiado. De este modo, los del Dulce Nombre, fundado para recogimiento de mujeres arrepentidas en 1540, el de Nuestra Señora de la Paz, 1571 y el de la Encarnación, 1591, serán de una etapa muy posterior ${ }^{27}$. En la actualidad solo persisten el de San Leandro y el de la Encarnación, los otros dos desaparecieron durante la desamortización.

20. Pastor Torres 2006, p. 179.

21. Borrero Fernández, 1992a, 1992 b.

22. Miura Andrades 1999, p. 144; Morgado 1587, p. 146.

23. Ortiz de Zúñiga 1796, p.154.

24. Carmona Moreno 2007, p. 170.

25. Como así lo afirma la profesora Borrero Fernández 2004, p. 51. No obstante, en algunas partes del presente trabajo, como veremos si será pertinente hacer aclaraciones y citar a autores que afirman que la existencia del de San Leandro, ya se mencionaba en documentación alrededor de 1260, así como otros que lo relacionan directamente con la fecha de la Conquista de Sevilla.

26. Borrero Fernández 2004, p. 51.

27. Arana de Varflora, 1789, pp.61-62. 


\section{LA FUNDACIÓN}

El Real Monasterio de San Leandro, perteneciente desde su fundación a la Orden de San Agustín, es uno de los más importantes y antiguos de la ciudad de Sevi1la. Aunque como muchos historiadores afirman no conocemos la fecha exacta de la fundación de este Convento ${ }^{28}$. Pero, por contra, parece ser que ya existía hacia el año 1260 cuando aparece citado entre las mandas de un testamento que recogió Ortiz de Zúñiga ${ }^{29}$. Si algo es evidente de por sí es el hecho de que si el monasterio de San Leandro existe es porque fue fundado. Como ya hemos mencionado, en relación a las fechas los autores de la época y otros de fechas posteriores divagan ${ }^{30}$, también los documentos conventuales. Parece igualmente seguro que a finales del siglo XIII, en 1286, existía un edificio bajo esta advocación pues en una donación a la Catedral de Sevilla se hace referencia al mismo como topónimo ${ }^{31}$.

Afirma José María Miura que lo más seguro es que en ese momento ya fuera convento, pues sobre la zona situada en torno a la puerta de Córdoba, en el año 1309, existían documentos y donaciones de Fernando IV. Posteriormente, bajo la concesión definitiva y confirmatoria de Pedro I, en 1367 se autorizó formalmente el traslado a la calle Melgarejos ${ }^{32}$, en la collación de San Marcos. Este traslado ya veremos que se realizó años antes, ya que otra donación en este caso realizada por un canónigo de la Catedral de Sevilla en 1309 revela cómo el edificio del primitivo Monasterio, situado extramuros, ya estaba abandonado en septiembre de 1309. No

28. Miura Andrades 1999, p. 145.

29. Ortiz de Zúñiga 1796, p. 236. "Subsistían ya también en toda forma los Conventos de San Pablo, San Francisco, la Merced, la Trinidad y San Leandro: para todos y para su obra hay legados pios en un testamento de este año (1260); al de San Leandro, que es su primer memoria, dice para los Cofrades de San Leandro; é á las devotas Monjas que allí moran: vese que había ya Cofradía y morada de mujeres Religiosas con título de San Leandro..."

30. Morgado 1587, pp. 450-453. Dató la fundación del Monasterio en el año de 1295, de manos de Fernando IV, “quarenta y siete años después de que se ganó Sevilla, fundó un monasterio de monjas de la orden de san Augustin, con invocacion y titulo del glorioso Prelado y Patrono de Sevilla san Leandro, de los muros a fuera de la ciudad". Pero claro el mismo autor cuenta su conflicto con el mayordomo de la comunidad, ya que ésta aceptó el acceso al archivo en un primer momento, pero en una segunda visita, cuenta el autor, que el mayordomo desaconsejó a la comunidad el donar las llaves de los cajones de las escrituras y privilegios antiguos, por miedo a él perder su mayordomía, obteniendo Morgado la datación "confusamente" por otras vías, como el mismo indica. Luego dudamos de la fiabilidad de los datos de datación del Monasterio. Confróntese en este mismo sentido Tirón 1846, p. 426.

31. Miura Andrades 1999, p. 145.

32. LPMSL 1666, cuad. 1, f. 4v. Atendiendo a la documentación real confirmamos el traslado por Privilegio de Pedro I en el año de 1367, aunque estamos seguros que se realizó anteriormente como beaterio de piadosas mujeres con la bendición de Fernando IV. Ya que como explicaremos a continuación lo inhóspito del lugar extramuros tras la conquista de la ciudad, hizo que las monjas pasaran periodos de calamidad y les fuera por tanto imposible el establecimiento en paz en aquel predio. El lector puede preguntarse el por qué de tantos años para obtener la perceptiva licencia, podemos atribuir la demora en tan oficioso menester debido a diferentes razones: la ineficacia de las comunicaciones o simplemente la relajación en las formas y respuestas o bien por la corona que asistió a años convulsos de cambios y periodos de transición inestables. También pudo deberse a las mismas monjas que acomodadas en la nueva casa vieron innecesario el demandar la legalización de la nueva situación en el mejorado enclave intramuros. 
concluye aquí el peregrinar de las monjas de San Leandro por la ciudad, pues hasta el año 1369 no se asentaron definitivamente en unas casas en la collación de San Ildefonso, donde actualmente se encuentra el Convento.

Del mismo modo, si atendemos al riquísimo archivo conventual, los datos vuelven a divagar pero nos ofrecen noticias diferentes. Del libro de Protocolo ${ }^{33}$ no se tiene constancia del mismo hasta los tiempos del rey Fernando IV (1295$1312)^{34}$, pero otros documentos del archivo monacal ${ }^{35}$ relatan la existencia de éste poco después de la conquista de Sevilla. Así lo recogen cronistas e historiadores ${ }^{36}$ como Ortiz de Zúñiga y, citando a este autor y tras el impresionante estudio archivístico realizado a finales del siglo XIX y principios del siglo XX, Antonio Ballesteros y Beretta, cataloga a San Leandro como monasterio de fundación fernandina. Relatando el elenco de casas religiosas fundadas en tiempo de san Fernando, como las de San Clemente o la de los Trinitarios, en el lugar donde las santas Justa y Rufina recibieran el martirio, este autor afirma que:

\begin{abstract}
Más allá, frente a la Puerta de Córdoba, en el sitio conocido con el nombre del Degolladero de cristianos, habitaban las monjas agustinas de San Leandro. Alli por lo solitario del lugar y la impunidad consiguiente, las dueñas sufrían los agravios de hombres poco escrupulosos, que las vejaban en mil formas y maneras ${ }^{37}$.
\end{abstract}

33. LPMSL 1666. El libro becerro utilizado para nuestro estudio se trata de un registro realizado en 1666 que recoge todas las propiedades, tributos y capellanías recibidas por el Monasterio con anterioridad a dicha fecha. Se encuentra dividido en diferentes cuadernos. El que nos ocupa se encabeza con los anagramas de Jesús, María y José. Seguido de la leyenda: "Protocolo y razón de las posesiones de casas, huertas, tributos, cortijos del monasterio de San Leandro de Sevilla de la Orden de San Agustín nuestro padre, y memoria de las capellanías que se sirven en la iglesia y sacado de su original por Bernabé Sánchez de Ortega, mayordomo de el dicho Monasterio que al presente lo hizo por este año de 1666. El cual tralado saco por le hacerlas memoria y buena obra la dicha hacienda y respecto de que su original no salga a los riesgos que se pudieran ofrecer como cada día se ofrecen en los oficios el hurtar los libros y papeles y más fácil si del buen cobro fecho es principio y nota retenida en Sevilla el 28 de noviembre de dicho año de 1666”. Firma Bernabé Sánchez de Ortega. LPMSL 1666, cuad. 1, f. 2r. En nota marginal un amanuense redactó sin más relación que el acceso al trono de Fernando IV, rey cuyo privilegio es el más antiguo que se documenta, lo siguiente: "Nota. El monasterio de San Leandro fuera de la puerta de Córdova estaba fundado el año de 1295 -que fue quarenta y siete años después de que ganó a Sevilla el santo rey Don Fernando".

34. LPMSL 1666, cuad. 1, f. 2r. Privilegio. Fernando IV. 5 de noviembre de 1309, ms.

35. AMSL. Memoria y Tradición de la venida de la milagrosa Imagen de María Santísima con el Amabilísimo título de las Virtudes, y milagros que la Señora ha obrado por mediación de esta hermosísima y devota Imagen. Sevilla, 1 de octubre de 1817, ms., anotaciones en diferentes libros de cuentas de diferentes siglos, ms. y otros legajos del archivo conventual donde se recogen los orígenes del mismo, ms.

36. Arana de Varflora 1789; Gestoso 1889; González de León 1884; González de León 1839; Madrazo 1884; Ortiz de Zúñiga 1796 y sus continuadores Antonio María Espinosa y Justino Matute y Gaviria. Así como: La sección especial del archivo municipal de Sevilla, que comprende los papeles y documentos adquiridos por el Excmo. Ayuntamiento de la testamentaría del Sr. Conde del Águila. Comunidades religiosas. Convento de monjas de San Leandro, tomo I, número 15, hay dos relaciones, ms.

37. Ballesteros Beretta 1913, pp. 133-154. Antonio Ballesteros Beretta quien, con sus estudios dedicados a Sevilla en el siglo XIII, permitió conocer documentos hasta entonces inéditos y dispersos en los archivos de la Catedral, del Ayuntamiento y de los monasterios de San Clemente, Santa Clara y San Leandro. Prosiguió luego su labor con una monumental biografía de Fernando III, que permanece 
En este sentido, el profesor Julio González, en su estudio sobre el Repartimiento de Sevilla, al tratar la cuestión de los monasterios llamados fernandinos -es decir, aquellos a los que la tradición sitúa en época del rey conquistador-, añade que, en realidad, todos son tardíos mencionando como tales los de San Clemente, Santa Clara, San Agustín y Santa María de las Dueñas ${ }^{38}$. Al decir San Agustín y citar los otros tres grandes monasterios femeninos, entendemos que el autor con este apodo no se refiere a la "Casa Grande" masculina, sino al femenino de San Leandro que profesa la misma Regla, dotándole la denominación de fernandino y, por tanto, retrotrayendo su fundación al periodo de la Conquista o poco después.

Con todo lo aportado podemos pensar, y creemos que acertadamente, que el origen por tanto es fernandino ${ }^{39} \mathrm{y}$ anterior al siglo XIV. Aun así si esta hipótesis no es la correcta es muy próxima, ya que, en palabras del historiador agustino Llordén, si afirmativamente tenemos constancia documental del asentamiento de los religiosos agustinos en Sevilla en el año de 1249, estos harían todo lo posible para que las religiosas de su misma Orden obtuvieran un recinto en la recién conquistada ciudad de Sevilla ${ }^{40}$. Del mismo modo, podemos suponer que la reunificación y reordenación de diferentes piadosas uniones bajo la Regla de San Agustín realizada con las citadas reformas de 1244 y 1256, en la Orden Agustiniana, pudiera dar oficialidad a monasterios femeninos ya creados. Estos monasterios suponemos que aún no gozaban de dicha visualización como pertenecientes a la Orden Agustiniana debido a lo reciente de la reunificación y que a partir de entonces pasaron a oficializarse como tales.

\subsection{Primer emplazamiento}

Ampliando lo anteriormente expuesto, podemos intentar trazar la trayectoria así como los distintos avatares por los cuales las monjas tuvieron que pasar hasta asentarse, definitivamente, en la collación de San Ildefonso, pues llegaron a cambiar hasta en dos ocasiones de establecimiento. En primer lugar hemos de acudir a la zona de extramuros, aquella que llamaban "Degolladero de los cristianos", ya que según recoge el citado historiador Ortiz de Zúñiga, el nombre se entiende por haber acabado en él <los cuellos de los cristianos sevillanos> a los filos del cu-

aún inédita. Éste cita en su libro el periodo de fundación fernandino: “...a la puerta de Cordoba que en el tiempo que era la villa, de moros que degollaban en aquel logar, do es este Monesterio, todos los cristianos, que creían en Dios, e en Santa María, e que era llamado aquel logar el degolladero de los cristianos... et porque las monjas de este Monesterio moran fuera de la villa que reciben muy grand agrauio et daño et menoscabo de muchos omes que no recelan a Dios nin a los Santos que i son que les face $\mathrm{z}$ les dicen cosas desaguisadas que son contra Dios z contra nuestro seruicio...", fol. 65, Argote de Molina, Aparato para la Historia de Sevilla, ms. en poder del Excelentísimo señor Duque de T'Serclaes.

38. González González 1988, pp. 360-361. La problemática en torno a las fechas de fundación de estos monasterios fernandinos fue analizada, tomando como ejemplo el Real Monasterio de San Clemente, en Borrero Fernández 1988, pp. 69-81.

39. González Jiménez 2006; González González 1986; Martínez Díez 1993; Mitre Fernández 1974; Rodríguez López 1994.

40. Llordén 1956, p. 9. 
chillo mahometano, en las persecuciones del tirano Abderramán, rey de Córdoba, que llenó de crueldades toda esta provincia ${ }^{41}$. En este sentido sí se recogen noticias del mismo en el Protocolo del Monasterio, afirmando que durante el reinado de Fernando IV:

El mismo se encontraba fuera de los muros de la ciudad, junto a la Puerta de Córdoba, y como éste tuvo que tomar bajo su protección, a causa de los muchos agravios e insultos que recibían las religiosas y el detrimento que experimentaban en sus bienes, lo inhóspito del lugar, las escasas condiciones de salubridad del sitio, infestado a la vez de gentes perversas, amigas del robo y hábiles para el saqueo, amparadas en la oscuridad de la noche y protegidas por bandas incontrolables, cometían mil tropelias, que la ley no podía con eficacia castigar, quebrantando asi la paz y el sosiego de las religiosas, expuestas siempre al pillaje de todo género y a perecer a manos de gentes desalmadas ${ }^{42}$.

Evidentemente, tras esta descripción tan precisa y terrible del mayordomo de la época, es fácil entender el deseo de las monjas de cambiar de residencia, ya que con aquellas circunstancias el cumplir sus votos y ejercicios era bastante difícil. Es por ello por lo que acudieron al rey. De esta forma se hace necesario acudir a los Privilegios Reales para constatar esta realidad, siendo el primero de los privilegios del que gozó este Monasterio el otorgado por Fernando IV. Haciéndose eco del padecer de las religiosas en pleno cerco de Algeciras y consciente de la obligación que tenía de proteger y defender a las religiosas en tan calamitosa situación, otorgó privilegio en 1309:

Don Fernando por la gracia de Dios rey de Castilla, de Toledo, de León... a todos los concejos, alcaldes, justicias, merinos, alguaciles, maestres... e a todos los homes de las villas e lugares de mis reinos, que esta mi carta vieren o el traslado de ella firmado o signado de escribano público, salud e gracia. Sepades que por facer bien e merced a las monjas e a los cofrades de San Leandro el viejo, que es en Sevilla, e porque rueguen a Dios por mí e por el ánima del rey Don Sancho, mio padre, que Dios perdone, recibi en mi gracia y encomienda a las dichas monjas e a los dichos cofrades e a todas sus cosas, por ende doy privilegio que pasten sus ganados y anden sus homes libres por todo mí reino sin pagar cosa alguna y les doy otras libertades y exenciones contenidas en el dicho privilegio, escrito en pergamino y sellado de plomo, de la una parte las armas de Castilla y león, y de la otra parte Santiago a caballo. Despachado sobre el cerco de Algeciras en 5 de noviembre de $1309^{43}$.

Este primer privilegio no tuvo una efectividad práctica y las monjas continuaron siendo insultadas y encontrándose desprotegidas, ya que los actos se repetían,

41. Ortiz de Zúñiga 1796, pp. 42 y 43.

42. LPMSL 1666, cuad. 1, f. 2r. Privilegio. Fernando IV. 5 de noviembre de 1309, ms.

43. LPMSL 1666, cuad. 1, f. 3v. Privilegio. Fernando IV. 5 de noviembre de 1309, ms. Este privilegio fue confirmado años después por su hijo Alfonso XI en Sevilla a 13 de marzo de 1331, ms., como afirma el protocolo. 
a pesar del favor real y de que el rey, por sucesivas cartas plomadas de 15 de $\operatorname{agosto}^{44}$ y 8 de noviembre ${ }^{45}$ de 1309 , dirigidas a la abadesa doña Lorenza, penara gravemente a sus ofensores y a quienes se atreviesen a molestarlas.

Si nos detenemos en la redacción del documento extraemos diversas noticias, como ya observara el padre Llordén: la existencia de las monjas, lo que implica un monasterio, la existencia de una cofradía ${ }^{46}$ dedicada a San Leandro, de unos ganados y unos trabajadores de dicho monasterio cuyo ganado gozaba de libertad deambulatoria ${ }^{47}$. Todo ello nos revela que el Convento ya llevaba tiempo erigido.

\subsection{Segundo emplazamiento}

La comunidad estaba dispuesta a cambiar de emplazamiento, pero no fue hasta tiempos del rey Pedro I cuando oficialmente lo consigan. De acuerdo con el citado Protocolo monacal, fue este rey quien otorgó la merced para erigir el Monasterio, confirmada con un privilegio de 8 de septiembre de 1367, en unas casas que ya poseía la comunidad en la collación de San Marcos. Así lo recoge el Privilegio:

Don Pedro por la gracia de Dios rey de Castilla, de León.., por cuanto por parte de la abadesa y monjas del monasterio de San Leandro, que estaba situado fuera de los muros de esta ciudad, junto a la Puerta de Córdoba, le fue suplicado diciendo que ellas y el dicho monasterio por estar fuera de la ciudad recibia muchos detrimentos, trabajos, injurias y fatigas en sus personas y bienes, que por tanto les hiciese merced que el dicho monasterio se quitase de alli y se fundase y situase en unas casas que ellas compraron, habían y tenían dentro de la dicha ciudad, en la collación de San Marcos, que fueron de Juan García, criado de Ruy González, de Manzanedo. Las cuales casas y monasterio que alli se fundase gozase de las libertades y franquezas que el dicho monasterio de la Puerta de Córdoba solía gozar y gozaba. Y el dicho rey don Pedro tuvo por bien, por devoción que tenía al dicho monasterio, cofrades y monjas de él, y porque rogasen a Dios por su vida y salud, y por el ánima del rey Don Alfonso XI, su padre, y los otros reyes de donde é1 venía, y concedióles los mismos privilegios, exenciones y libertades que el dicho monasterio antes tenía, y mandólos guardar so las penas en ellos impuestas, según que más largo se contiene en el dicho privilegio, que fue dado en Sevilla en 8 de septiembre de $1367^{48}$.

44. LPMSL 1666, cuad. 1, f. 2v. Privilegio. Fernando IV. 15 de agosto de 1309, ms.

45. Id. Privilegio. Fernando IV. 8 de noviembre de 1309, ms.

46. Pérez González 2005b, p. 266. En dicha publicación se hace referencia a una documentación de 1496 donde se recoge y documenta por primera vez el Hospital y Cofradía de San Leandro y Santa María Magdalena. Puede ser que la misma, haga referencia a esta agrupación de cofrades que se recoge en el citado y anterior privilegio y que la documentación encontrada sea posterior. En los documentos estudiados del AMSL no aparece una documentación reseñable sobre esta cofradía o su fundación. "Hospital y Cofradía de S. Leandro y Sta. María Magdalena. Se documenta por primera vez en 1496. El hospital se encuentra en la collación de Santa María en la calle Lino. Celebra su advocación en la iglesia de Santa María. Es la cofradía de un oficio concreto: el de los corredores de lonja”.

47. Llordén 1973, p. 11.

48. LPMSL 1666, cuad. 1, f. 4v. Privilegio. Pedro I. 8 de septiembre de 1367, ms. 
Pero en el propio Privilegio encontramos una contradicción, ya que habla del Monasterio que "estaba" en la zona del Degolladero de los cristianos, luego ya no estaba. Y al mismo tiempo que se quitase de allí y se fundase en unas casas que la comunidad tenía en San Marcos, luego sí estaba. Y si a ello le añadimos que Ortiz de Zúñiga recoge que el rey Fernando IV, a las monjas agustinas concedió en 10 de junio de 1310 real licencia para entrarse en Sevilla, donde habian comprado una casa en la parroquia de San Marcos, en la calle llamada de los Melgarejos, en que dieron principio a su nuevo monasterio ${ }^{49}$, nos lleva a pensar que efectivamente las monjas se trasladaron intramuros por licencia de Fernando IV, pero como piadosas mujeres, sin estar jurídica o canónicamente reconocido el segundo edificio en 1310. Y no será hasta tiempos de Pedro I, en 1367, cuando se concedió merced por este monarca para erigir el Monasterio dentro de la ciudad en las casas de la collación de San $\operatorname{Marcos}^{50}$, donde posiblemente vivía la comunidad -ya que eran de su propiedad-, y conforme los privilegios otorgados a dicho Monasterio que se encontraba inicialmente en la zona llamada del "Degolladero de los Cristianos".

Ahondando en el devenir del primer emplazamiento, lo primero que nos planteamos es que pasó con el anterior edificio. Recoge Ortiz de Zúñiga ${ }^{51}$ que la iglesia que quedó en el primer emplazamiento dedicada a San Leandro y que formaba parte del que era el primitivo Monasterio del mismo nombre, fue asistida por una comunidad de varones píos ${ }^{52}$. El autor, cuando recogió estas palabras, incluyó la expresión: que ya había en ella -refiriéndose a la comunidad de varones píos-, lo que nos confirma que siguiendo la teoría planteada, la comunidad de religiosas agustinas abandonó el primer emplazamiento anteriormente a la confirmación oficial de Pedro I, en 1367. Dicha iglesia siguió dedicada al culto del mismo san Leandro, y de igual modo siguió siendo honrada por el rey y sus descendientes lo que nos indica la concesión de diferentes gracias y privilegios. Además, haciéndose eco de una piadosa tradición, dice en sus Anales el citado autor que fueron muchos los que pensaron que en aquél lugar también se encontró el templo dedicado a las santas Justa y Rufina, fundado por el mismo san Leandro en el tiempo de su prelacía. Por ser dicho templo de su fundación, la tradición aporta que en aquel lugar fue enterrado él mismo -san Leandro-, así como sus hermanos san Isidoro y santa Florentina. Tras la conquista de Sevilla en 1248 fue la misma ciudad quien quiso darle allí culto a su memoria, resucitando el templo donde estuvo aquél tan celebrado, y entre cuyas ruinas discurren que es posible se halle el mismo san Leandro, aporta Ortiz de Zúñiga. Pero el autor apostilla que realmente no se sabe el lugar exacto donde fue enterrado, que se trata de meras conjeturas, que lo único

49. Ortiz de Zúñiga 1796, p. 42.

50. LPMSL 1666, cuad. 1, f. 4v. Privilegio. Pedro I. 8 de septiembre de 1367, ms.

51. Ortiz de Zúñiga 1796, p. 60.

52. LPMSL 1666, cuad. 1, f. 4v. En este lugar se encuentra ahora un convento de religiosos capuchinos, erigido en las casas propiedad hasta entonces de las monjas agustinas, cuyo derecho y señorío dieron en 1627 para la citada fundación. Antes de convento de San Leandro fue "ermita dedicada a las santas vírgenes". 
cierto es que había convento y cofradía de San Leandro y que se llamaba todo aquel campo el "Degolladero de los Cristianos"

El lugar es hoy en día la actual Ronda de Capuchinos, donde se encontraba la puerta de Córdoba y aún hoy la Iglesia de San Hermenegildo, construida en la destruida muralla. Respecto al cuerpo de san Leandro, es cierto que nunca se encontró el mismo, pero que existe reliquia mayor de primer grado de este santo, concretamente un fragmento de su tibia que de tiempo inmemorial las monjas agustinas poseen y exhiben el día de su onomástica para la veneración pública. Ésta se encuentra protegida por una antiquísima ampolla de cristal recubierta con cadenas de plata, y según se relata en sus archivos y libros de milagros ${ }^{54}$, acontecieron muchos por medio de la intercesión y del contacto con tan importante reliquia.

\subsection{Tercer emplazamiento y definitivo}

Retomando la cuestión del emplazamiento tras los problemas de fechas y contradicciones encontradas, podemos afirmar que en 1369, dos años después de su traslado oficial a San Marcos, las monjas se desplazaron de nuevo. Esta vez a su emplazamiento definitivo, unas casas frente a la parroquia de San Ildefonso ${ }^{55}$. En el Protocolo no se mencionan los motivos del cambio, sino simplemente la generosidad del rey y la donación hecha por Pedro I en favor del monasterio de San Leandro. Es evidente que el nuevo emplazamiento intramuros era inmejorable y muy próximo al centro urbano de Sevilla. Por ello, las monjas se trasladaron a esas casas respondiendo al favor y la merced de Don Pedro I. El rey lo confirmó como el que era: monasterio de San Leandro, así como también confirmó todos sus anteriores privilegios.

Otro motivo del cambio de emplazamiento pudo estar en las dimensiones del nuevo. El anterior emplazamiento de San Marcos pudo ofrecer a las monjas incomodidad y estrechez para la realización de sus actividades, y el nuevo, indudablemente mucho más extenso, daba lugar a un sitio donde poder edificar sobre todo iglesia capaz para la celebración de los cultos religiosos y litúrgicos. Era un establecimiento mucho más amplio, con variadas dependencias útiles y cómodas, donde practicar otros menesteres que por obligación o por simple afición debían

53. Ortiz de Zúñiga 1796, p. 43.

54. AMSL. Memoria y Tradición de la venida de la milagrosa Imagen de María Santísima con el Amabilísimo título de las Virtudes, y milagros que la Señora ha obrado por mediación de esta hermosísima y devota Imagen. Sevilla, 1 de octubre de 1817, ms., y otros legajos del archivo conventual donde se recogen las crónicas del mismo, ms.

55. Cuando las monjas se trasladan a la parroquia de San Ildefonso, el edificio de aquella época no coincide con el que actualmente podemos observar, ya que existen datos en los libros de cuentas del siglo XVIII, ms., sobre la aportación por parte de las monjas de una cuota fija a las fábricas de distintas iglesias, hospitales y conventos, entre ellos la Iglesia del señor San Ildefonso, luego se entiende que ésta estaría en construcción en época posterior, existiendo un edificio anterior y distinto en el momento del tercer emplazamiento. 
emprender y ordenar, así en el orden material como en el espiritual ${ }^{56}$. No debemos olvidar que la iniciativa partía de la voluntad del rey y de su liberalidad, ya repetida, en favor de las monjas, la cual no podía ser despreciada y éstas debían aceptarlo, por supuesto complacidas por el obsequio real que suponía un lugar aún más céntrico que el anterior.

Recoge el Protocolo del Convento la donación que escasos dos meses antes de su fallecimiento, pues murió en 23 de marzo de $1369^{57}$, concedió a la comunidad de San Leandro el rey Pedro I. Se trata de las casas en las que a día de hoy continúa, con algunas añadidas posteriormente:

Don Pedro por la gracia de Dios rey de Castilla, de León... Por cuanto Teresa Jufre (hija del almirante Don Alonso Jufre Tenorio) mujer que fue de Alvar Díaz de Mendoza, hizo y habló algunas cosas contra el servicio del dicho señor rey, por lo cual cayó en caso de perdimiento de todos sus bienes, los cuales pertenecían para la su cámara, para los dar y donar a quien él quisiere y por bien tuviere. $Y$ por esta causa y por hacer bien y merced a doña Catalina, abadesa del convento de San Leandro y a las demás monjas de él, por tanto le dio y donó las casas que la dicha Teresa Jufre había y tenía en esta ciudad, en la collación de San Ildefonso, que habian por linderos de la una parte casas de Juan Fernández, su mayordomo, y de la otra casas de Fernán Ruiz Cabeza de Vaca y las calles reales, para hacer y edificar en ellas el dicho monasterio. Para lo cual manda a todos los alcaldes y justicias de esta ciudad, a quien la su carta de merced fuere mostrada o su traslado signado de escribano público, den y entreguen a la dicha abadesa y monjas, o a quien su poder hubiere, las dichas casas y las metan en tenencia y posesión de ellas y las amparen y defiendan, porque alli se haga el dicho monasterio de San Leandro, y que les hagan guardar las libertades y franquezas que de antes se les solían guardar, cuando estaba situado y fundado fuera de la Puerta de Córdoba. Dada en Sevilla en 19 de enero de $1369^{58}$.

La ventura de las religiosas de San Leandro, por el contrario, fue la desdicha de Doña Teresa Jufre. Y es que la relación de Pedro I con la familia Jufre Tenorio cayó en desgracia y fue la enemistad personal del mismo rey la que la llevó a su ocaso. El célebre almirante sevillano Don Alonso Jufre Tenorio sucedió en los repartimientos y casa de Don Jufre de Loaisa su abuelo. Tuvo el Almirante muchos hijos, entre ellos el mayor Garci Jufre Tenorio, alguacil mayor y alcalde mayor de Sevilla, a quien mandó matar el rey Don Pedro I en el año 1367. Destaca también su hija Doña Urraca, quien recibió la mayor parte de los heredamientos de su padre siendo la legítima heredera con capacidad para heredar. Por último, la mencionada Doña Teresa Jufre Tenorio, mujer y posteriormente viuda de Don Alvar Díaz de Mendoza, cuyas casas confiscó el rey Don Pedro y dio para el convento de San Leandro en $1369^{59}$, debido a que ésta cayó en caso de perdimiento de todos

56. Llordén 1973, p. 13.

57. Díaz Martín 1995, p. 369.

58. LPMSL 1666, cuad. 1, f. 4v. Privilegio. Pedro I. 19 de enero de 1369, ms.

59. Ortiz de Zúñiga 1796, pp. 303 y 304. 
sus bienes por hablar mal del servicio del rey ${ }^{60}$. No es de extrañar la acción de la señora ya que el citado monarca condujo el linaje de su padre y el suyo propio prácticamente a la extinción ${ }^{61}$.

El copista que confeccionó el Protocolo, donde se recogen todas las escrituras, documentos, mercedes y privilegios recibidos por el Monasterio, prosigue su labor y, después de recordar la donación del rey Don Pedro, afirma que establecida la comunidad definitivamente en las casas de Teresa Jufre:

Persevera en ellas y resplandece con grandes y continuos ejemplos de virtud, religión y santidad por las religiosas que ha tenido y tiene de nobilísimos linajes y ferviente servicio de nuestro Señor, acudiendo al culto conforme a su Regla y Estatutos, fundando memorias y capellanías, como se verá por la razón que de ellas se pondrá en este protocolo ${ }^{62}$.

Por tanto, podemos concluir que el monasterio de San Leandro de Sevilla sufrió en sus inicios el traslado de su emplazamiento hasta en tres ocasiones. La primera erección con su primitiva casa fundacional se realizó en la zona extramuros llamada del "Degolladero de los Cristianos", donde estuvo desde su fundación -cuya fecha exacta desconocemos-, hasta que por motivos de inseguridad tuvo que desplazarse dentro de las murallas de la ciudad. Se cree que este desplazamiento se realizó por licencia de Fernando IV, en 1310. Pero no será hasta 1367, cuando mediante Privilegio de Pedro I y de manera oficial, se realice el traslado a las casas de la calle Melgarejos, en la collación de San Marcos, como monasterio de San Leandro. Aunque como ya ha quedado probado las monjas realizarían este traslado con anterioridad como agrupación de piadosas mujeres. Dos años más tarde -1369-, el mismo rey Don Pedro I concederá licencia y donará a las mismas monjas un nuevo emplazamiento, frente a la parroquia de San Ildefonso, en la collación que lleva su mismo nombre. Allí será trasladada la comunidad, recibiendo todos los privilegios y concesiones anteriormente confirmados en los distintos emplazamientos. Este último, es el actual y definitivo emplazamiento hasta nuestros días ${ }^{63}$.

60. López de Ayala 1779, p. 531.

61. Sánchez Saus 2002, p. 398.

62. LPMSL 1666, cuad. 1, f. 4v. Privilegio. Pedro I. 19 de enero de 1369, ms.

63. La finalización de la construcción del monasterio fue muy rápida, en menos de ocho años ya se encontraba terminado. Este dato aparece en el AMSL, como legajo en pergamino firmado por Don Diego Rodríguez, donde por mandato del señor arzobispo Don Fernando Carrillo de Albornoz, el chantre de la Santa Iglesia, Don Bartolomé Rodríguez, bendijo el monasterio e iglesia de San Leandro. El escribano concretó que la bendición se realizó para que fuese cementerio y entierro de las religiosas del Monasterio y de las demás personas que allí quisieran inhumarse. El documento fue firmado en Sevilla el sábado día 18 de julio de 1377. 


\section{Fusión con el Emparedamiento de San Pedro}

Resulta de gran importancia en la comprensión del estudio que realizamos en dicho periodo, la incorporación al monasterio de San Leandro de la comunidad de religiosas de San Pedro, así como sus propiedades y rentas en el siglo XVI. Para comprender esta fusión es necesario aclarar distintos puntos en relación a las formas en las que se desarrolló el movimiento religioso femenino, así como el contexto de cambio religioso, social y político del citado siglo.

\subsection{Contexto}

El siglo XVI trajo consigo transformaciones en todos los órdenes y niveles, el deseo de cambio, ya sea en el ámbito civil como en el religioso, pretendió la regulación y la uniformización de los nuevos acontecimientos y avatares que surgían conforme al nuevo cambio de mentalidad. Toda esta regulación fue siempre bien vista, en tanto y cuando que se desarrollase dentro de un ambiente de reforma y de renovación. Este ambiente fue el vivido dentro de la vida religiosa del citado siglo y que, finalmente, desembocó en las grandes reformas del siglo XVI. Reformas que la Iglesia ansiaba desde el pasado siglo XIV y que supusieron el gran resurgir de la misma y de aquellos que pretendieron regeneracionarla. Estas actitudes regeneracionistas y reformistas fueron compartidas por todos los estamentos sociales, aunque las pretensiones fueron diferentes conforme a la posición social de cada uno ${ }^{64}$.

Tenemos que remontarnos a mediados del siglo XIII, cuando el monacato tradicional castellano entró en crisis y ante esta debilidad aparecieron pronto aquellos que alzaron la voz con movimientos de reforma, que fueron apodados como Observancia, buscando siempre el adaptar el monacato a las nuevas demandas sociales $^{65}$. Posteriormente, la segunda mitad del siglo trajo consigo una fuerte crisis económica y social que afectó también al monacato y su sistema. La profesora Cavero encuentra una serie de factores concretos a la afectación de esta crisis: por ejemplo la separación de las mesas (abacial y conventual), el fenómeno de la encomienda (a la búsqueda de la protección nobiliar laica) y la crisis agrícola (malas cosechas y una climatología adversa). En esta línea, el estudio de los archivos monacales aporta también una fuerte caída en cuanto a documentación referente a compraventas, donaciones y apeos por parte de los conventos, además de los problemas con las jurisdicciones señoriales que cada vez eran más acentuados ${ }^{66}$.

64. Para intentar explicar la reforma, la medievalista francesa Adeline Rucquoi afirmó que la misma fue "une affaire social". "Un affaire de tous: une affaire spirituelle, mais également morale et politique pour les grands qui fondent des communautés observantes et protègent les réformateurs: morale et eschatologique pour les élites urbaines qui prennent le parti des observants et les favorisent dans leurs dernières volontés; une affaire où se mélagent les éléments du merveilleux, du milléniarisme et de la revendication sociales pour les plus défavorisés. Mais d'une façon ou d'une autre, l'affaire de tous". Rucquoi 1987, p. 250.

65. García Oro 1980, pp. 211-213.

66. Cavero Domínguez 2012a, p. 12. 
Todos estos factores eran un avance de la gran crisis posterior del siglo XIV que provocó un fuerte menoscabo en los ámbitos socioeconómico, político y espiritual, teniendo a la peste como origen y fin de todos sus males. Es por ello que a la crisis espiritual del monacato se le suma la económica, perdiendo éste gran parte de sus rentas debido a la disminución de la superficie cultivable provocada por el descenso demográfico o por la política usurpadora de la nobleza ${ }^{67}$.

De otro lado, el monacato tradicional se encuentra con el auge vertiginoso, a finales del siglo XIII, de las órdenes mendicantes que desplazaron el interés de las futuras vocaciones así como de la sociedad, sus donaciones y rentas a su nuevo modelo de vida. A este gran auge habría que sumar las nuevas fórmulas religiosas adoptadas por el mundo laico, ajenas al claustro, entiéndanse por éstas, beaterios, así como la que nos ocupa, emparedamientos y otras fórmulas similares ${ }^{68}$. Éstas se constituyeron en un grupo alternativo y muy fuerte al monacato claustral tradicional bajomedieval que gozó de mucho éxito sobre todo en el mundo femenino ${ }^{69}$. Fue dentro de este ambiente de renovación donde las mujeres desempeñaron un papel fundamental, tomando la iniciativa durante las primeras décadas en cuanto a la opción de las nuevas fórmulas laicales así como su contacto con las órdenes mendicantes y sus terceras órdenes, en un primer momento muy interesadas por el desarrollo de este auge de movimientos laicales. Este desarrollo se produjo a través de la creación de espacios espirituales y vivenciales propios, contribuyendo a dar forma y a enriquecer el movimiento religioso femenino ${ }^{70}$, que en el citado siglo XIII comenzaba a brillar con luz propia ${ }^{71}$. Este movimiento religioso femenino estaba basado en el mismo Humanismo reformista en este caso femenino, donde reforma y novedad aparecen estrechamente trabadas en la experiencia femenina. El movimiento femenino buscaba la oficialización y el reconocimiento de los proyectos realizados por las mujeres, dándoles mayor visibilidad, además de un lugar eclesial reconocido y aceptado oficialmente contribuyendo a la autosignificación femenina en una sociedad, un medio eclesial y una cultura formulados por hombres en sus propios términos. Además, la creación institucional incidía sobre las estructuras preexistentes y otorgaba a las mujeres capacidad para manipularlas y definirlas, crear mundos y espacios relacionales nuevos en el centro de las convenciones sociorreligiosas de su tiempo ${ }^{72}$.

67. Durán y Castrillo 1995, pp. 147-164. Duran Castrillo 2014, p.111.

68. "Se perciben interrelaciones entre emparedadas, beaterios y beatas en las collaciones de mayor densidad religiosa laica y en el origen de sus espacios". "Pero el fenómeno beato mostró una plasmación vital y una proyección eclesial diferentes a las emparedadas”. Graña Cid 2012, pp. 711 y 715.

69. Sobre el tema de las beatas sus orígenes y su paso a la vida monacal, así como su relación y distinción con los emparedamientos y otras fórmulas laicales debe consultarse; Graña Cid 2010; 2011; 2012 .

70. Sobre el movimiento religioso femenino en general, sin afán de exhaustividad, puede verse: Bolton 1977. La clásica obra de Grundmann 1980; Leclercq 1980; Pasztor 1984; Benvenuti Papi 1990; Barone 1994; Sensi 1995; Graña Cid 2010. Citado por Álvarez Rodríguez 2015, p. 13.

71. Álvarez Rodríguez 2015, p. 13.

72. Graña Cid 2015, p. 86. 
En la ciudad de Sevilla esta creación de espacios de dedicación espiritual para mujeres, laicales y a-institucionales, pues no dependían en principio de ninguna institución, llegaron de manos de las propias mujeres (movimiento laico) a partir del siglo XIV -emparedamientos y sobre todo beaterios-. Los mismos fueron dominando el ámbito de la creación de espacios religiosos durante la segunda mitad del siglo y la primera mitad del siguiente, para pasar a ser institucionalizadas posteriormente en un ambiente más monástico y de mayor control eclesial. Y es que cualquier tipo de planteamiento espiritual autónomo o a-institucional que brotara durante estos últimos años sufrió un progresivo proceso de control por parte de la jerarquía eclesiástica. Esta institucionalización de la vida religiosa revistió especial intensidad cuando dichas propuestas alternativas eran experimentadas por el sector femenino. En este sentido asistiremos a dos grandes tendencias que bien recoge la profesora Graña Cid. Por un lado, la paulatina institucionalización laica con la aparición de nuevas fisonomías beatas y de nuevas realidades claustrales como los conventos de terciarias regulares. Y de otro, la reactivación y desarrollo de las fundaciones monásticas, una de cuyas manifestaciones principales fue la conversión de beaterios y conventos de terciarias en monasterios. Esta iniciativa femenina fue condicionada y/o sustituida por los titulares masculinos, sobre todo a partir de 1495, siendo la reforma promovida por los Reyes Católicos y Cisneros ${ }^{73}$.

Esta inclusión institucional por parte de la Iglesia y la monarquía supusieron el inicio del fin de las tradiciones medievales durante el siglo XVI. La época coincidió con la gran expansión demográfica y económica de la ciudad, auspiciada por la concesión a su puerto del monopolio del tráfico con las Indias. La ciudad se hizo grande y populosa. El auge sevillano condujo a la proliferación de donaciones, que facilitaron la labor fundacional, en un ambiente religiosamente tenso y rico: las nuevas órdenes y las renovadas se extendieron sobre la ciudad con el telón de fondo, como ya hemos visto, de la Reforma y la Contrarreforma ${ }^{74}$. Es un momento histórico donde se impulsó y floreció de una manera extraordinaria la fundación de conventos, solo en la ciudad de Sevilla se fundaron en este periodo un total de treinta y cinco cenobios. Las fundaciones ya no son reales, sino que pasaron a ser exclusivamente iniciativa de la nobleza titulada y de los grupos oligárquicos. Mientras al mismo tiempo declinaron otras formas de religiosidad de tradición medieval, como los emparedamientos, de los que sólo quedaron tres en el siglo XVI. O los beaterios donde se recogían mujeres siguiendo la regla de una orden ${ }^{75}$. Fue en este contexto y siglo donde se entiende como indicara Ortiz de Zúñiga:

En él se extinguieron alguno de los emparedamientos de mujeres virtuosas que había en Sevilla, que se repartieron por los Conventos, y en el de San Leandro se incorporó enteramente el emparedamiento de San Pedro de su misma Regla de San Agustín, en virtud de Bulas Apostólicas, que era el de mas comunidad y hacienda ${ }^{76}$.

73. Graña Cid 2015, p. 77.

74. Fernández Terricabras 2007; Madrigal 2005; Martínez Rojas 2007; Pérez Blázquez 2010.

75. Pérez Cano 1995.

76. Ortiz de Zúñiga 1796, p. 279. 


\subsection{Emparedamientos}

Para abordar correctamente el fenómeno de los emparedamientos la profesora Cavero $^{77}$ nos introduce en las fuentes donde encontrar la institución, ofreciéndonos un elenco de las mismas a la hora de estudiar estas formas religiosas hispánico medievales. Resalta a la hora de abordar su estudio que los emparedamientos no contengan fuentes propias y que tengan que ser todas ellas de carácter indirecto: eclesiásticas, concejiles, crónicas, obras literarias y hagiográficas y todo tipo de documentación que aporte noticias de este singular modo de ascetismo, sin duda, el más radical de cuantos se desarrollaron en la búsqueda de la perfección ${ }^{78}$.

La reclusión religiosa fue una forma de vida ascética ligada al mundo eclesiástico en general, monástico en particular, desde la época tardorromana. Esta reclusión fue entendida como búsqueda de la perfección y se mantuvo en el medio monástico y conventual, pasando en los siglos XII y XIII, a las nuevas formas de la vita apostolica que marcaron el cambio en el comportamiento espiritual de los laicos. Ha sido femenina y masculina, pero fue más común entre las mujeres; su cenit va de la mano con el movimiento terciario y fue una fórmula desarrollada individual o comunitariamente ${ }^{79}$. Como hemos dicho anteriormente, la reclusión femenina de los emparedamientos debe entenderse como movimiento a-institucional, aunque debido a su carácter parroquial ${ }^{80}$ posee cierta vinculación a las instituciones siendo menos autónomos que los beaterios.

A pesar de la entrada en crisis, durante el siglo XVI, de los modelos de religiosidad tradicional medievales, como ya hemos citado, en un momento anterior, la existencia de mujeres que de forma espontánea se retiraban a un lugar apartado o se recogían con el fin de vivir una vida religiosa fue un fenómeno frecuente y bastante extendido en la Península Ibérica Medieval ${ }^{81}$. La profesora Cavero Domínguez definió el emparedamiento como aquél que constituía un género de vida esencialmente urbano. Las emparedadas, con frecuencia, solían situarse en estancias próximas a iglesias, capillas, ermitas, puertas de las murallas, puentes, hospitales, etc., experimentando, por lo general, un género de vida recluido. El grado de reclusión podía ser variable, encontrándose reclusiones definitivas o temporales, así como, individuales o colectivas ${ }^{82}$.

Si bien en las fuentes monásticas altomedievales se habla de reclusión (inclusi, reclusi), cuando en los siglos plenomedievales se generaliza en la vida laical, el término hispánico que se aplica es emparedamiento, que responde al de enmura-

77. Gran especialista en el tema de los emparedamientos. Confróntese su estudio Cavero Domínguez 2010, en todo lo referente a terminología y evolución de los mismos. Así como, Mcvoy 2010.

78. Cavero Domínguez 2006, p. 106.

79. Cavero Domínguez 2006, p. 105.

80. Graña Cid 2013, p. 372.

81. Pérez González 2005a, p. 91.

82. Para comprender el emparedamiento medieval en la Península Ibérica es necesario leer y citar a la profesora Cavero Domínguez 2010. 
miento ("encarcerate", "cellane", "murate"), que se usa en otros países europeos ${ }^{83}$. Aun así el vocablo recluso-a (soror reclusa) no desaparece de la documentación bajomedieval ${ }^{84}$. En general, la historiografía insiste en que la reclusión o el emparedamiento fue un fenómeno más desarrollado en el ámbito femenino, voluntario, ascético, piadoso ${ }^{85}$ y protegido por la realeza ${ }^{86}$. Fueron muy populares entre la población, así mismo hubo fuertes lazos de unión y protección entre estos y diferentes referentes sociales: la jerarquía eclesiástica ${ }^{87}$, las nacientes órdenes mendicantes (franciscanos y dominicos) ${ }^{88}$, las parroquias ${ }^{89}$ y los propios concejos.

\subsection{Emparedamiento de San Pedro}

En el caso que nos ocupa, el emparedamiento de San Pedro llegó a su ocaso como muchos otros de la ciudad, y si atendemos brevemente al Archivo monacal y a las Bulas Papales que a continuación citaremos, el proceso de unión con el monasterio de San Leandro fue convulso, aunque finalmente llegó a buen término. Ignoramos la fecha en que fue inaugurado y erigido el emparedamiento que existía junto a la parroquia de San Pedro en la ciudad de Sevilla. La profesora Pérez González recoge que se documenta por primera vez en el Archivo Histórico Provincial de Sevilla, en $1492^{90}$, pero por el trabajo realizado en cuanto a la aportación de sus bienes al convento de San Leandro sabemos que fue anterior ${ }^{91}$. De sus emparedadas sabemos que observaban la Regla de San Agustín, como ya citó el creador de Los Anales, y estaban sujetas a la obediencia del señor arzobispo.

Las emparedadas sevillanas no respondían a un modelo de vida contemplativo y cercano al ideal monástico: No guardaban clausura individual, no vivían de la caridad pública, sino que desarrollaron una vida activa en contacto con el mundo ${ }^{92}$ y no hacían votos públicos monásticos de pobreza, obediencia y castidad, aunque posiblemente todas los hacían privados. Sí compartían con el ideal monástico el que las personas que habitaban estas casas sí llevaban una vida común, luego aún siendo emparedadas observamos que su forma de vida guardaba mayor semejanza con la de los beaterios. Melquíades Andrés define esta manifestación de la religio-

83. Para el caso francés véase L’Hermite-Leclercq, 1989, 1997. Para Italia los estudios de Benvenuti Papi 1984, 1990. Citado por Cavero Domínguez 2006, p. 106.

84. Cavero Domínguez 2006.

85. Cavero Domínguez 2012b, p 61.

86. Benito Ruano 1989, p. 120.

87. Multitud de actos realizados a favor de los emparedamientos así como testamentos y donaciones personales de los prelados. Destaca el testamento del Cardenal Juan de Cervantes, arzobispo de Sevilla quien equipara a religiosas y emparedadas como rezadoras de salmos, y deja a todas las de la ciudad una suma para que lo hagan por su alma y la de sus familiares. ACS, F.H.G., caja 107, doc. 17.2, Sevilla, 16 de noviembre de 1453. Véase también Moreno Núñez 1985.

88. Miura Andrades 1991a, 1998.

89. Recoge Morgado que en el siglo XVI existía un emparedamiento por cada Iglesia parroquial. Miura Andrades 1991b, p. 144.

90. AHPSPN. Leg. 17418. f. 96r. Citado por Pérez González 2005a, p. 98.

91. Guijo Pérez 2017.

92. Pérez González 2005a, p. 95. 
sidad bajomedieval como una espiritualidad que sale de los conventos y se abre a todos, con la consolidación del fenómeno laical, valoración de lo femenino con el aumento del culto a María, y espiritualidad que exalta la oración mental y la vida interior frente a los actos externos (ritos, ceremonias, oración verbal, etc. $)^{93}$.

En este contexto histórico y religioso, anteriormente visto, se entiende que el arzobispo de Sevilla Don Diego de Deza decretara que este Emparedamiento se convirtiese en monasterio y las emparedadas fuesen monjas, sujetas a la obediencia de su abadesa. Debe recordarse que en este periodo el Emparedamiento ya se encuentra sujeto a la prelacía del Ordinario de Sevilla, ya que anteriormente era al Prior General de Castilla a quien se encontraba sometido ${ }^{94}$. La actitud del arzobispo respondió al control eclesiástico que quiso ejercerse sobre los emparedamientos y las emparedadas, ya que se observó una fuerte relajación en las costumbres de las emparedadas, sobre todo en la zona meridional de la Península. Un sínodo sevillano de $1490^{95}$ registró abundantemente en este asunto:

Hemos sabido que en las iglesias de esta ciudad, como en toda nuestra diócesis, hay muchos emparedamientos en los cuales hasta ahora no se ha guardado el encerramiento debido, lo cual trae mal ejemplo y podría ser causa de daño para las conciencias de algunos emparedados o de otras personas; por ello, queriendo poner remedio, mandamos que, de aqui en adelante, estén encerradas, por manera que ni ellos salgan fuera ni otra persona, varón ni hembra, de cualquier estado o condición que sea, entre dentro sin nuestra licencia ${ }^{96}$.

Los obispos con esta actitud mostraron su malestar por la situación de los emparedamientos y seguían las directrices al mismo tiempo del reino. Como bien recoge la profesora Cavero, ciertamente la política de los Reyes Católicos, con la reforma de Cisneros, cambió las actitudes a partir de los últimos años del siglo XV. Se hizo necesario un mayor control de las experiencias religiosas femeninas extraclaustrales, y los obispos pusieron las bases para un control del emparedamiento ${ }^{97}$.

En este contexto las quince religiosas que formaban la comunidad de San Pedro se vieron obligadas a seguir las instrucciones de Don Diego de Deza por obediencia, pero dudaron sobre la legalidad de las mismas. Don Diego de Deza había observado en su diócesis la relajación de estas instituciones, en Sevilla

93. Andrés Martín et al. 1980, p. 325. Citado por Pérez González 2005a, p. 92.

94. LPMSL 1666, cuad. 1, f. 6r. Además mediante la Bula Papal de S.S. Paulo III. 9 de febrero de 1542 se pone de manifiesto este hecho confirmando que las religiosas se encuentran bajo la tutela del arzobispo: "Dudando pues vosotras, según poco ha nos hicisteis exponer, si en atención a que separadas de los religiosos de vuestro orden, vivís en la costumbre de ser visitadas por el arzobispo de Sevilla, que por tiempo es, y a él estáis sujetas, podréis usar y gozar de las gracias e inmunidades del orden de los ermitaños de San Agustín". Un ejemplar de esta Bula, en latín y castellano, existe en el Archivo del Ayuntamiento de Sevilla, Comunidades Religiosas, tomo I, núm. 14. Confróntese también Tirón, 1846, p. 426.

95. Sánchez Herrero 1996. En relación a los emparedamientos véase el capítulo XXV.

96. Sánchez Herrero 1982, p. 321

97. Cavero Domínguez 2012b, p. 72. 
existió incluso la figura del visitador de emparedamientos ${ }^{98}$. Por tanto fue necesario tomar medidas y corregir la situación poniendo en práctica las disposiciones del Sínodo. Ante la duda de la comunidad por la disposición del arzobispo, solicitaron por ajustarse a las leyes canónicas la ratificación del Sumo Pontífice, acto que no se había realizado. Por esta causa acudieron al Papa Julio II (1503-1513) suplicándole confirmase lo dispuesto y ordenado por el arzobispo hispalense. Su Santidad por una Bula ${ }^{99}$ dada en Roma, a 15 de enero de 1508, confirmó la disposición arzobispal, les concedió facultad para que pudiesen denominar al monasterio con la advocación y nombre que más devoción tuviesen y licencia para que pudiese continuar el monasterio en el mismo sitio o en otro honesto, donde mejor les pareciese.

Los emparedamientos habían ofrecido una imagen débil y escandalosa con respecto a sus orígenes fundacionales durante la posterior etapa bajomedieval. Por ello la corrección impuesta desde la jerarquía eclesiástica pretendía que estos fueran viables únicamente por la línea institucional en el marco conventual y monástico. Es cierto que no fue el mismo control para las ramas masculinas y femeninas. Cuando se trataba de feminae devotae, la Iglesia no veía más que la clausura como solución adecuada ${ }^{100}$. El papado favoreció estas transformaciones desde la cancillería pontificia con la concesión de bulas ${ }^{101}$. Y aunque el concilio de Trento no legisló específicamente sobre los emparedamientos, otorgó poder a las jerarquías eclesiásticas para ejercer un control sobre las personas que desarrollaban vida eremítica y, sobre todo, marcó la actividad sinodal sobre un exhaustivo control disciplinario y las competencias de autoridad episcopal sobre los eremitas, reclusos, beatas y otras fórmulas solitarias ${ }^{102}$.

La comunidad de emparedadas de San Pedro sufrió el tránsito de aquel género de vida a otra más monacal, regulada por distintas disciplinas, usos y costumbres pero del mismo modo surgieron las dificultades del local para poder practicar con puntual observancia la asistencia al coro, donde habían de rezar cotidianamente el oficio divino, así como para otros actos de comunidad. Además, eran pocas en número, desiguales en la edad, algunas probablemente inválidas por los años o postradas por las continuadas penitencias, cuya exención de tales actos comunes era forzoso otorgarles. Las pocas útiles de que podían disponer tendrían que emplearse en la asistencia y cuidado de las enfermas e incapaces, todo en detrimento de la vida conventual y de la regular observancia ${ }^{103}$.

Estas circunstancias adversas motivaron que a los pocos años elevaran una petición al Sumo Pontífice León X (1513-1521) para que les permitiera unirse a

98. Pérez González 2005b, p. 93.

99. LPMSL 1666, cuad. 1, f. 6r. Bula Papal de S.S. Julio II. 15 de enero de 1508.

100. Cavero Domínguez 2012b, p. 73.

101. Sirva como precedente a nuestro emparedamiento de San Pedro, la bula que sancionó la transformación de las emparedadas de la iglesia de San Miguel de Sevilla en Nuestra Señora de la Antigua de Utrera, bajo la protección de Alonso Álvarez Chamorro, durante el papado de Julio II, en 1505. Wadingo 1883, pp. 632-633. Citado por Cavero Domínguez 2012b, p. 73.

102. Orlandis Rovira 1970. Citado por Cavero Domínguez 2012b, p. 73.

103. Llordén 1973, p. 20. 
las religiosas de San Leandro, y les concediese gracia y licencia para que pudiesen hacer la incorporación sin ninguna contradicción. En efecto, el Papa accedió a sus deseos por la Bula del 16 de mayo de $1516^{104}$ en la que expresa:

Por cuanto por parte del convento de San Pedro, abadesa y monjas de él, le fue suplicado y hecha relación diciendo que ellas estaban en aquel monasterio, el cual era muy angosto y pequeño y ellas pocas monjas, que no pasaban de diez y seis, querían con sus bienes muebles y raices incorporarse en el monasterio de San Leandro, en la collación de San Ildefonso, debajo de la obediencia del arzobispo, como lo estaban.

Por tanto, accediendo a la petición de las religiosas les concedió la gracia y licencia para incorporarse con las otras monjas del monasterio de San Leandro. La agregación no debió verificarse a gusto de todas, como suele acontecer en tales casos, y ante la disparidad de pareceres y diferencia de criterios, sobrevino la disociación de las voluntades y una nueva e imprevista separación. La fusión del emparedamiento de San Pedro con el convento de San Leandro se había hecho en conformidad con la misiva enviada a Roma por las monjas y dispuesto en la Bula pontificia. Apunta el Protocolo que después la abadesa de dicho emparedamiento de San Pedro -Eugenia de San Pedro- obtuvo con "siniestra relación" ciertas bulas que autorizaban la salida de San Leandro para reincorporarse en el suyo, como de hecho así sucedió, llevando consigo los bienes que pudo y arrastrando en pos de sí a otras que con ella habían venido ${ }^{105}$.

Es por ello que a vista de estos hechos desagradables la abadesa y convento de San Leandro suplicaron a la Santidad de León X confirmase la Bula, y con ella diese autoridad canónica y comisión suficiente a varios jueces apostólicos para que dictaminaran sobre el inesperado acontecimiento. El Pontífice aceptó el recurso interpuesto, despachó sus bulas y dio comisión plena al Maestrescuela de la Catedral, al Prior de San Agustín y al de Santo Domingo de Porta Coeli, los cuales aprobaron y confirmaron la incorporación e hicieron volver a dichas monjas de San Pedro con los bienes muebles y raíces que habían llevado al convento de San Leandro, como todo consta por los autos hechos en $1516^{106}$.

Una vez aclarado el asunto y al fusionarse finalmente el emparedamiento de San Pedro con el convento de San Leandro en 1516, éste recibió los bienes que aquel poseía ${ }^{107}$.

104. LPMSL 1666, cuad. 1, f. 6v. Bula Papal de S.S. León X. 16 de mayo de 1516.

105. Prosigue el copista en el libro de protocolo seguido a la redacción de la Bula Papal de S.S. León X. 16 de mayo de 1516, id.

106. Llordén 1973., p. 21.

107. Guijo Pérez 2017. 


\section{CONCLUSIÓN}

Tras haber estudiado los orígenes del Real Monasterio de San Leandro podemos concluir que el mismo tiene su nacimiento en el contexto de la conquista de Sevilla, pudiendo reconocerse como de origen fernandino y anterior al siglo XIV. Las constancias documentales no son explícitas en cuanto a su origen como fecha de fundación en sí misma, pero los avatares históricos y contextuales pueden llevarnos a afirmar ésta en el periodo que nos ocupa.

La situación de una Sevilla extramuros no muy controlada ni documentada, la presencia de agrupaciones de piadosas mujeres en distintos establecimientos en la misma ciudad y sus alrededores, la generalización de la Regla de San Agustín y las unificaciones papales bajo esta Regla en 1244 y 1256, y la pronta llegada de los agustinos a la ciudad, pueden llevarnos igualmente a pensar que esta comunidad era ya existente. No contamos con constancias documentales de la oficialidad de su fundación directamente y aquellas donde fue reconocida indirectamente son de un momento posterior -encontramos alusiones de 1260 y 1286-, a pesar de ello no se desvirtúa el fundamento de nuestra teoría.

Del mismo modo, resulta significativo en nuestro estudio el haber hecho mención a la fusión que el Monasterio tuvo con la comunidad de religiosas de San Pedro en 1516 -Emparedamiento de San Pedro-, como un hecho transformante tanto de la comunidad de San Leandro como de su patrimonio en los últimos momentos medievales de la historia de la ciudad de Sevilla. Se trata de un acontecimiento que recoge el resultado de los cambios de tendencias y avatares religiosos, sociales, políticos e históricos de la Península Ibérica, y como la posición y voz de la mujer empezó a abrirse paso en un mundo de hombres. El momento social impidió una mayor profusión de este movimiento femenino y así el emparedamiento sufrió en un primer momento la claustración para vivir conforme al monacato tradicional y una fusión posterior al monasterio de San Leandro para realizar un mayor control sobre las mismas. Con estas actuaciones se seguían las indicaciones reales de Isabel y Fernando, y las disposiciones religiosas en la materia del Cardenal Cisneros, así como se ponían en práctica las disposiciones promulgadas en el Sínodo de Sevilla de 1490.

Anterior y posteriormente a la fusión con el emparedamiento de San Pedro, no hemos dejado de ver el favor real, papal, eclesiástico y social del que gozó durante todo este periodo el Real monasterio de San Leandro, así como la importancia del mismo en el entramado urbano de la ciudad de Sevilla y entre sus habitantes. Del mismo modo, constatamos ese favor para con el emparedamiento de San Pedro, aunque finalmente a la hora de la fusión fuera la voz del sentido común y la ley quien otorgase a San Leandro el reconocimiento en la reclamación de su derecho. 


\section{BIBLIOGRAFÍA CITADA}

Álvarez Rodríguez, Alicia (2015), “De beatas a monjas dominicas: el proceso de constitución del monasterio de Santa Catalina de Sena de Zamora a finales del siglo XV", Hispania, vol. LXXV, 249, enero-abril, pp. 11-38.

Andrés Martín, Melquíades; García-Villoslada, Ricardo; González Novalín, José Luis; Lopetequi, León; Marcos, Balbino; Rodríguez G. de Ceballos, Alfonso; Rubio, Samuel; (1980), Historia de la Iglesia de España, La Iglesia en la España de los siglos XV y XVI, vol. III-2 ${ }^{\circ}$, Madrid.

Anónimo (1700), Para la historia de el convento de N. P. S. Agustín de Sevilla escrita en 1700.

Aramburu Cendoya, Ignacio (1966), Las primitivas Constituciones de los Agustinos, Valladolid.

Arana de Varflora, Fermín (1789), Compendio histórico descriptivo de la muy noble y muy leal ciudad de Sevilla, Sevilla.

Azevedo, Antonio (1699), Compendio historial de los ermitaños de N. P. San Agustín en el principado de Cataluña, Barcelona.

Ballesteros Beretta, Antonio (1913), Sevilla en el siglo XIII, Madrid.

Barone, Giulia (1994), "Società e religiosità femminile (750-1450)", en Lucetta Scaraffia y Gabriella Zarri, Donne e fede. Santità e vita religiosa in Italia, Roma, Editorial Laterza, pp. 61-113.

Benito Ruano, Eloy ed. (1989), Libro del limosnero de Isabel la Católica, Madrid.

Benvenuti Papi, Anna (1984), "Velut in sepulchro : cellane e recluse nella tradizione agiografica italiana", Culto dei santi, istituzioni e classi sociali in età preindustriale, Boesch Gajano S., Sebastiani L. eds., (Collana di Studi storici, 1), Roma, pp. 365-456.

Benvenuti Papi, Anna (1990), "In castro poenitentiae”. Santità e società femminile nell'Italia medievale, Roma, Herder.

Bolton, Brenda M. (1977), "Mulieres sanctae", Women in medieval society, ed. Susan Mosher Stuard, University of Pennsylvania Press, Philadelphia, pp. 141-158.

Borrero Fernández, Mercedes (1988), "Tradición y realidad en la fundación de San Clemente de Sevilla", Archivo Hispalense, 216, Sevilla, pp. 69-81.

Borrero Fernández, Mercedes (1992a), El archivo del Real Monasterio de San Clemente. Catálogo de documentos (1186-1525), Sevilla.

Borrero Fernández, Mercedes (1992b), El Real Monasterio de San Clemente. Un monasterio cisterciense en la Sevilla medieval, Sevilla.

Borrero Fernández, Mercedes (1995), "Iglesia-Monarquía en la Sevilla Bajomedieval", Sevilla, ciudad de privilegios. Escritura y poder a través del privilegio rodado, Sevilla, pp. 83-117.

Borrero Fernández, Mercedes (2004), "El monasterio cisterciense de Santa María de las Dueñas. Sevilla. Siglos XIII-XVI”, Historia, Instituciones, Documentos, 31, Sevilla, pp. 51-68. 
Carmona Moreno, Félix (2007), “Conventos agustinianos de Sevilla y su desamortización”, en Francisco Javier Campos y Fernández de Sevilla (coord.), La desamortización: el expolio del patrimonio artístico y cultural de la Iglesia en España: actas del Simposium 6/9-IX-2007, pp. 167-190.

Cavero Domínguez, Gregoria (2006), "Fuentes para el estudio del emparedamiento en la España Medieval (siglos XII-XV)", Revue Mabillon, 17, pp. 105-126.

Cavero Domínguez, Gregoria (2010), Inclusa intra parietes. La reclusión voluntaria en la España medieval, Toulouse, Université de Toulouse II-Le Mirail.

Cavero Domínguez, Gregoria (2012a), "El monacato medieval en el Noroeste Ibérico", Primer Congreso Territorial del Noroeste Ibérico, Intecca Uned, Ponencia 5-11-2012, pp. 1-15.

Cavero Domínguez, Gregoria (2012b), “Obispos y sínodos hispanos ante el emparedamiento bajomedieval", Medievalismo: Boletín de la Sociedad Española de Estudios Medievales, 22, pp. 57-74.

Cilleruelo, Lope (1966), El monacato de San Agustín, Valladolid.

Crusenius, Nicolás (1623), Monasticum Augustinianum, Munich.

Díaz Martín, Luis Vicente (1995), Pedro I. 1350-1369, Diputación Provincial de Palencia, Palencia.

Durany Castrillo, Mercedes (1995), Rodríguez González, María del Carmen, "La crisis del monacato berciano en la Baja Edad Media", El Monacato en la Diócesis de Astorga durante la Edad Media, Ayuntamiento de Astorga, pp. 147-164.

Durany Castrillo, Mercedes (2014), Rodríguez González, María del Carmen, "El espacio berciano en la Edad Media, punto de partida", Mundos medievales: Espacios, sociedades y poder, ed. Bolamburu Arízaga, Beatriz; Mariño Veiras, Dolores; Díez Herrera, Carmen; Peña Bocos, Esther; Solórzano Telechea, Jesús Ángel; Guijarro González, Susana; Añíbarro Rodríguez, Javier, vol. I, Santander.

Empoli, Laurentino (1628), Bullarium Ordinis E. San Augustini, Roma.

Estrada Robles, Basilio (1988), Los Agustinos Ermitaños en España hasta el siglo $X I X$, Madrid.

Fernández Terricabras, Ignasi (2007), “Éxitos y fracasos de la Reforma católica. Francia y España (siglos XVI-XVII)”, Manuscrits, 25, págs. 129-156.

Frías, Lorenzo (1956), "Introducción de la Regla agustiniana en España", La Ciudad de Dios, número 169, pp. 506-535.

Gago Fernández, Luis (1963), Trayectoria histórica de la escuela agustiniana, Bogotá.

García Oro, José (1980), "Conventualismo y Observancia. La reforma de las órdenes religiosas en los siglos XV y XVI”, Historia de la Iglesia en España, vol. III-1, Madrid.

Gavignan, John (1962), De vita monastica in Africa septemtrionali inde a temporibus sancti Augustini usque ad invasiones Arabum, Roma.

Gavignan, John (1989), The Augustinians from the French Revolution to the modern times, Villanova, Estados Unidos.

Gestoso, José (1889), Sevilla monumental y artística, Sevilla. 
Gil Prieto, Juan (1930), "La Orden Agustiniana durante los pasados siglos en Sevilla", en Archivo Agustiniano, 35.

González González, Julio (1986), Reinado y diplomas de Fernando III, Ed. Caja de Ahorros y Monte de Piedad de Córdoba, Córdoba.

González González, Julio (1988), El Repartimiento de Sevilla, Sevilla.

González Jiménez, Manuel (2006), Fernando III el Santo, Fundación José Manuel Lara, Sevilla.

González de León, Félix (1884), Noticia histórica, artística y curiosa de todos los edificios públicos, sagrados y profanos de de esta Muy Noble, Muy Leal, Muy Heroica e Invicta Ciudad de Sevilla, y de muchas casas particulares, Sevilla.

González de León, Félix (1839), Noticia histórica del origen de los nombres de las calles de Sevilla, Sevilla.

Graña Cid, María del Mar (2008), Espacios de vida espiritual de mujeres. (Obispado de Córdoba, 1260-1550), Directora: Cristina Segura Graíño, Tesis Doctoral. Universidad Complutense de Madrid.

Graña Cid, María del Mar (2010), Religiosas y ciudades: la espiritualidad femenina en la construcción sociopolítica urbana bajomedieval, (Córdoba, siglos XIII-XVI), Asociación Hispánica de Estudios Franciscanos, Córdoba.

Graña Cid, María del Mar (2011), "Beatas dominicas y frailes predicadores. Un modelo religioso bajomedieval de relación entre los sexos (Córdoba 14871550)", Archivo Dominicano, 32, Salamanca, pp. 219-246.

Graña Cid, María del Mar (2012), "Beatas y comunidad cívica. Algunas claves interpretativas de la espiritualidad femenina urbana bajomedieval (Córdoba, siglos XIVXV)", Anuario de Estudios Medievales, 42/2, Madrid, pp. 697-725.

Graña Cid, María del Mar (2013), "Beatas y monjas. Redes femeninas y reforma religiosa en la ciudad bajomedieval", Ser mujer en la ciudad Medieval europea, en Solórzano Telechea, Jesús; Arízagha Bolumburu, Beatriz; Aguiar Andrade, Amelia, Logroño (eds.), pp. 371-388.

Graña Cid, María del Mar (2015), "Fundaciones conventuales femeninas y Querella de las Mujeres en la ciudad del siglo XV", Lusitania Sacra, 31, pp. 73-105.

Grundmann, Herbert (1980), Movimenti religiosi nel Medioevo. Ricerche sui nessi storici tra l'eresia, gli ordini mendicanti e il movimento religioso femminile nel XII e XIII secolo e sui presupposti storici della mistica tedesca, Bologna, Il Mulino.

Guijo Pérez, Salvador (2017), "Relación y formación del patrimonio urbano del monasterio de San Leandro de Sevilla. Siglos XIII-XVI.", Estudios sobre Patrimonio, Cultura y Ciencias Medievales, 19, pp. 609-634.

Gutiérrez, David (1980), (1977), (1971), Historia de la Orden de San Agustín, vols. I/I, I/II, II, Roma.

Herrera, Tomás de (1644), Alphabeticum Augustinianum, Madrid.

Herrera, Tomás de (1652), Historia del convento de San Agustín de Salamanca, Madrid.

Iturbe Saíz, Antonio (1994), "El convento de San Agustín de Sevilla y su patrimonio artístico", en Revista Agustiniana, 35, pp. 861-909. 
Jordán, Jaime (1704), Historia de la provincia agustiniana de la corona de Aragón, vols. I-IV, Valencia.

Leclercq, Jean (1980), "Il monachesimo femminile nei secoli XII e XIII", en Movimento religioso femminile e francescanesimo nel secolo XIII: atti del VII Convegno internazionale, Assisi, Società internazionale di studi francescani, pp. 61-99.

L'Hermite-Leclercq, Paulette (1989), Le monachisme féminin dans la société de son temps. Le monastère de La Celle (IX e siècle - début du X V Ie siècle), París.

L'Hermite-Leclercq, Paulette (1997), L'Eglise et les femmes dans l'Occident chrétien des origines à la fin du Moyen Age, Turnhout.

Llordén, Andrés (1944) "Los Agustinos en la Universidad de Sevilla”, en Archivo Hispalense, 4, pp. 151-173.

Llordén, Andrés (1956), "La Orden agustiniana en Andalucía", La Ciudad de Dios, 168, pp. 584-608.

Llordén, Andrés (1973), Convento de San Leandro de Sevilla, Málaga.

López de Ayala, Pedro (1779), Crónicas de los reyes de Castilla, vol. I, Madrid.

López Bardón, Tirso (1903), (1914), Monasticum Augustinianum Crusenii continuatio, vol. I, vol. II, Valladolid.

Madrazo, Pedro de (1884), España. Sus monumentos y artes. Su naturaleza e historia. Sevilla y Cádiz, Barcelona.

Madrigal, Santiago (2005), "Renovación y Reforma de la Iglesia: una perspectiva histórica", XXXI Curso de Teología, Ciclo III: en el V centenario de Santa Teresa de Jesús, Universidad de Cantabria, Aula de Estudios sobre la Religión, pp. 637-650.

Márquez, Juan (1608), Origen de los frailes ermitaños de la Orden de San Agustín y su verdadera institución antes del gran Concilio Lateranense, Salamanca.

Martínez de Aguirre, Javier (1992), "El refectorio de San Agustín y la asimilación del gótico en Sevilla", en Archivo Hispalense, 229, pp. 109-130.

Martínez Díez, Gonzalo (1993), Fernando III. 1217-1252, Ed. La Olmeda, Palencia.

Martínez Rojas, Francisco Juan (2007), “Trento: encrucijada de reformas”, Studia Philologica Valentina, vol. 10, 7, págs. 201-239;

Maturana, Víctor (1912), (1913), Historia General de los Ermitaños de San Agustín, vols. I-II, Santiago de Chile.

McAvoy, Liz Herbert ed. (2010), Anchoritic Traditions of Medieval Europe, Woodbridge: The Boydell Press.

Mitre Fernández, Emilio (1974), La España Medieval: Sociedades, Estados, Culturas, Ed. Itsmo, Madrid.

Miura Andrades, José María (1988), "Beatas y beaterios andaluces en la Baja Edad Media. Su vinculación con la Orden de Predicadores", Actas del V Coloquio de historia medieval de Andalucía. Andalucía entre Oriente y Occidente (1236-1492), Córdoba, pp. 527-535. 
Miura Andrades, José María (1991a), “Conventos, frailes y ciudades. Los dominicos y el sistema de jerarquización urbana de la Andalucía bajomedieval”, Actas del VI Coloquio de historia medieval de Andalucía. Las ciudades andaluzas (siglos XIII-XVI), Málaga, pp. 277-288.

Miura Andrades, José María (1991b), "Formas de vida religiosa femenina en la Andalucía medieval. Emparedadas y beatas", Muñoz Fernández, Ángela y Graña Cid, María del Mar (eds.), Religiosidad femenina: expectativas y realidades (ss. VIII-XVIII), Madrid, pp. 139-164.

Miura Andrades, José María (1999), Frailes, monjas y conventos: las Órdenes Mendicantes y la sociedad sevillana bajomedieval, Diputación Provincial de Sevilla, Sevilla.

Montes Romero-Camacho, Isabel (1987), "La Iglesia de Sevilla en tiempos de Alfonso X", Sevilla en tiempos de Alfonso X, Sevilla, pp. 158-221.

Moreno Núñez, José Ignacio (1985), "Semblanza y patrimonio de Don Sancho Blázquez, obispo de Ávila (1312- 1355)”, Hispania Sacra, 37, pp. 155-188.

Morgado, Alonso (1587), Historia de Sevilla, Sevilla.

Orlandis Rovira, José (1970), "La disciplina eclesiástica española sobre la vida eremítica", España eremítica, Pamplona, pp. 63-77.

Orozco, Alonso de (1551), Crónica del glorioso padre y doctor de la Iglesia, San Agustín y de los santos y beatos y doctores de su Orden, Sevilla.

Orozco, Alonso de (1824), Regla de nuestro gran padre y patriarca San Agustín, Madrid.

Ortiz de Zúñiga, Diego (1796), Anales Eclesiásticos y Seculares de la Muy Noble y Muy Leal, Ciudad de Sevilla, Madrid.

Pastor Torres, Álvaro (2006), La muchacha de bronce de Sevilla. Artículos y escritos hispalenses, editorial Turris Fortísima, Sevilla.

Pasztor, Edith (1984), "I Papi de duecento e trecento fronte alla vita religiosa femminile", ed. Roberto Rusconi, Il movimento religioso femminile in Umbria nei secoli XIII-XIV: atti del Convegno internazionale di studio nell'ambito delle celebrazioni per l'VIII centenario della nascita di S. Francesco d'Assisi, Nuova Italia Editrice, Perugia, Regione dell'Umbria, pp. 31-65.

Pérez Cano, María Teresa (1995), Patrimonio y ciudad: El sistema de los conventos de clausura en el centro histórico de Sevilla, Sevilla.

Pérez Blázquez, Aitor (2010), "El cambio de mentalidad colectiva: renacimiento, humanismo, reforma y contrarreforma", (Sección Temario de oposiciones de Geografía e Historia), Proyecto Clio 36, ISSN: 1139-6237, http://clio.rediris. es [consulta: 15/06/2017], pp. 1- 15.

Pérez González, Silvia María (2005a), Los laicos en la Sevilla Bajomedieval. Sus devociones y cofradias, Universidad de Huelva, Huelva.

Pérez González, Silvia María (2005b), La mujer en la Sevilla de finales de la Edad Media: solteras, casadas y vírgenes consagradas, Sevilla.

Purificación, Antonio de la (1642), Chronologia monástica lusitana, Lisboa.

Rodríguez, Ángel (1927), La Orden agustiniana durante 15 siglos, Pamplona. 
Rodríguez Díez, José (1992), "Historia de la Orden de San Agustín en la época de Fray Luis de León”, Edad de oro, 11, pp. 133-148.

Rodríguez López, Ana (1994), La consolidación territorial de la monarquía feudal castellana: expansión y fronteras durante el reinado de Fernando III, (ed.) Consejo Superior de Investigaciones Científicas, Madrid.

Román y Zamora, Jerónimo (1569), Crónica de la Orden de ermitaños del glorioso San Agustín, Salamanca.

Román y Zamora, Jerónimo (1571-1572), Primera y segunda parte de la historia de la Orden de los frailes eremitanos de San Agustín, Alcalá.

Rucquoi, Adeline (1987), "La réforme monastique en Castille au XVe siècle: une affaire sociale", en Henri Dubois y André Vauchez, Horizons marins, itinéraires spirituels. (Ve-XVIIIe siècles), Publications de la Sorbonne, 1, Paris, pp. 239-253.

Sánchez Herrero, José (1984), "Monjes y frailes. Religiosos y religiosas en Andalucía durante la Edad Media", Actas del III Coloquio de Historia Medieval andaluza: grupos no privilegiados, Jaén, pp. 405-456.

Sánchez Pérez, Emiliano (2001), "La Orden de San Agustín en Sevilla y patrimonio pictórico de los conventos del Pópulo y San Agustín”, Iconografía Agustiniana, Congreso Internacional de Historia de la Orden de San Agustín, Roma, pp. 369-437.

Sánchez Herrero, José (1982), "La Iglesia andaluza en la Baja Edad Media, siglos XIII al XV", Actas del I Coloquio de Historia de Andalucía. Córdoba, pp. 265-330.

Sánchez Herrero, José (1992), Historia de la Iglesia de Sevilla. Sevilla.

Sánchez Herrero, José; Pérez González, Silvia María (1996), "El sínodo de Sevilla de 1490”, Archivo Hispalense, 79, núm. 241, Sevilla, pp. 69-96.

Sánchez Saus, Rafael (2002), "Nuevos datos y sugerencias acerca del entorno sevillano de las primeras expediciones a Canarias", en la España Medieval, 25, pp. 381-401.

San Nicolás, Pablo de (1736), Siglos geronymianos: Historia general, eclesiastica, monastica y secular, vol. XI, Madrid.

Sanz Pascual, Atilano (1948), Historia de los agustinos españoles, Madrid.

Sensi, Mario (1995), Storie di bizzoche tra Umbria e Marche, Edizioni di storia e letteratura, Roma.

Tirón, Abate (1846), Historias y trages de las órdenes religiosas, Barcelona.

Trape, Agostino (1978), La Regla de San Agustín, Madrid.

Wadingo, L. (1883), Regesta Pontificum Romanorum, 1505, n. XX, Berlín. 